\title{
Sense about Science
}

\section{Public led, expert fed}

Scientific evidence, when used responsibly, has the potential to be a great power for good. However, our lives often revolve around claims based on litle, poor or poorly understood evence. Sense about Scitence is changing that: they director Tracey Brown about why and how they are doing this.

\begin{tabular}{|c|c|c|}
\hline $\begin{array}{l}\text { t the turn of the millennium, } \\
\text { public trust in science was at } \\
\text { an all-time low. Sense about } \\
\text { Science was set up to change that. } \\
\text { For nearly two decades now, the } \\
\text { organisation has been encouraging } \\
\text { scientists to take part in public } \\
\text { discussion and challenging the public } \\
\text { to ask for the evidence behind the } \\
\text { decisions made by politicians and } \\
\text { policy-makers. }\end{array}$ & $\begin{array}{l}\text { What is the core idea behind Sense } \\
\text { about Science? } \\
\text { The idea is that sound science and } \\
\text { evidence are a matter of public interest. } \\
\text { This means making sure that authorities } \\
\text { see that evidence matters to people } \\
\text { in all walks of life, and that they need } \\
\text { to be accountable for how they use or } \\
\text { portray science and evidence. It also } \\
\text { means making sure that people have } \\
\text { the tools to weigh up what they're told. }\end{array}$ & $\begin{array}{l}\text { claims that actually confront people } \\
\text { in different domains and work out } \\
\text { what critical thinking and research } \\
\text { evidence could bring to that. We are } \\
\text { particularly interested in drawing out } \\
\text { underlying assumptions and finding } \\
\text { key insights that help non-specialists } \\
\text { dig into a subject. Over the last } 18 \\
\text { years we have also opened up areas } \\
\text { where the evidence used in decisions is } \\
\text { systemically yobscured, such as in policy- } \\
\text { making, use of predictive models, and, } \\
\text { globally, clinical trial reporting. }\end{array}$ \\
\hline $\begin{array}{l}\text { In this interview, racey Brown, Director } \\
\text { of Sense about Science, tells Research } \\
\text { Outreach why they believe science and } \\
\text { evidence are a matter of public interest, } \\
\text { and how they are going about restoring } \\
\text { confidence in research today. }\end{array}$ & $\begin{array}{l}\text { We engage the help of people } \\
\text { across all areas of research, as well as } \\
\text { community leaders, good journalists } \\
\text { and politicians. Our approach to } \\
\text { subjects is 'public led, expert fed'; } \\
\text { that is, to start with the questions or }\end{array}$ & $\begin{array}{l}\text { Could you tell us a little bit about your } \\
\text { background and how you came to be } \\
\text { involved with the charity? } \\
\text { My path was headed towards social }\end{array}$ \\
\hline
\end{tabular}

We are particularly interested in drawing out underlying assumptions and finding key insights that help non-specialists dig into a subject.

research, but in the early 1990s spent time in Russia, developin EU collaboration to build up socind thing to experience society that had been unable to reflect openly on itself beginnin to use social statistics and test explanations, and to see the energy of a new generation of researchers wanting to help people to do this. It first alerted me to the idea of scientific thinking as public empowerment. 1 suspect Sense about Science's focus on accountability and transparency owes something to those days.

came out of that and into a situation in Europe in which science and society In the UK we'd had the BSE (or mad cow disease) crisis and controversies around the risks of technologies. without specialist kn those of us be equipping ourselves to ask critical questions and apply insights; an endeavour that researchers could help with. I met the late social psychologist Peter Marsh. We both came from less educated backgrounds and shared an appreciation for how empowering knowledge is. He introduced me to Lord Taverne, who had founded the Institute for fiscal Studies and was stang an organisation to improve that ince in public life, with a board

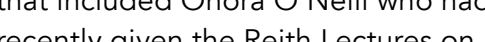
of Nature. I became the first member of staff. trust, and John Reith Lectures on

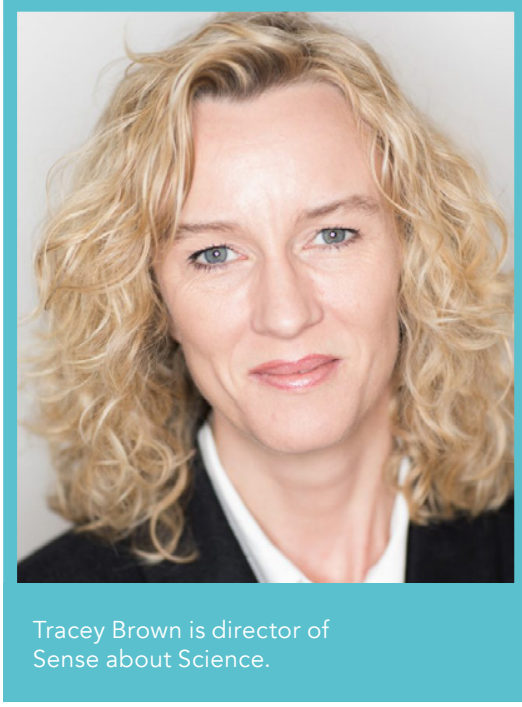

You have launched several campaigns and initiatives that encourage public disussion about scientific evidence. In in scruting? Our 'Ask for Evidence' campaign equips people to ask questions about what they re told - in adverts, news stories, policy announcements and more. It is primanly to help them small and sen if we were ten times bigger we wouldn't be able to pursue 
